\title{
Antibacterial activity of three Cameroonian honey types against some pathogenic species
}

\author{
Gerald NGO TEKE $^{1 *}$ and Betie Emile NGIENYIKEH ${ }^{2}$ \\ ${ }^{I}$ Department of Biomedical Sciences, Faculty of Health Sciences, University of Bamenda, P.O.Box 39, Bambili, \\ Cameroon. \\ ${ }^{2}$ Department of Medical Laboratory Sciences, Faculty of Health Sciences, University of Bamenda, P.O. Box \\ 39, Bambili. Cameroon. \\ *Corresponding author; E-mail: ngobob@yahoo.com ; Tel. (+237)675049577.
}

\begin{abstract}
Though much has been documented on the biological activity of honey, no scientific report was seen on the antibacterial activity of honey from Oku, Mbengwi and Ngaoundéré in Cameroon. Our aim was to study the in vitro antibacterial activity of honey produced from these places against clinical isolates. Honey samples were tested for antibacterial activity at concentrations from 100 to $20 \%$ volume per volume (v/v) against clinical bacterial isolates using agar well diffusion method. MICs and MBCs of honey samples (49.02 to $1.53 \%$ $\mathrm{v} / \mathrm{v})$ were determined using broth and agar media respectively. Ciprofloxacin was used as reference substance ( 120 to $0.5 \mu \mathrm{g} / \mathrm{ml}$ ). Honey $\mathrm{pH}$ was measured using CYBOW11 test strips. Data were analysed with the help of statistical package for social sciences (SPSS), version 19. These honey samples inhibited the studied bacterial growth at concentrations $\geq 40 \%$ with $S$. aureus and E. coli being more susceptible. Antibacterial activities at concentrations $>60 \%$ were comparable to that of the reference drug at $p=0.05$. The MICs and MBCs ranged from 12.25 to $49.02 \%$. The $\mathrm{pH}$ of honeys was estimated to be 5 . Oku, Mbengwi and Ngaoundéré honey samples showed antibacterial activity against some bacteria known to cause infectious diseases in humans.

(C) 2016 International Formulae Group. All rights reserved.
\end{abstract}

Keywords: Honey, inhibition zone diameter, MIC/MBC, clinical isolates, Cameroon.

\section{INTRODUCTION}

The use of honey in medicine dates far back in history. Many infections have been reported treated using honey (Anna et al., 2015). It has been used for dressing wounds (burns, surgical wounds, and skin ulcers) probably due to its antimicrobial activity (Amal, 2014; Manisha and Shyamapada,
2011) and also the fact that honey speeds up the growth of new tissues. It reduces pain and odour quickly (Lusby et al., 2002). Moreover, honey has served as offerings to gods and an embalming fluid (Amal, 2014).

Antibacterial and antifungal properties of honey against some microbial species have been reported (Chute et al., 2010; Kwakman 
et al., 2010). More recently, honey has been reported to have an inhibitory effect to many species of bacteria including aerobes and anaerobes, Gram positives, and Gram negatives (Maria et al., 2011).

The mechanisms involved in antibacterial activity of honey is linked to high osmotic nature and naturally low $\mathrm{pH}(3.2-4.5)$ (Kwakman and Zaat, 2012), ability to produce hydrogen peroxide (Subrahmanyam et al., 2001; Mahendran and Kumarasamy, 2015) and the presence of phytochemical factors such as tetracycline derivatives, peroxides, amylase, fatty acids, phenols, ascorbic acid, terpenes, benzyl alcohol and benzoic acid (Shears, 2000; Wasihun and Kasa, 2016). The use of honey as an alternative antimicrobial therapy could be attributed to the fact that it is easily availability, cheap, non-toxic and moreover bacterial resistance to it is yet to be reported (Zainol et al., 2013).

Several types of bacteria, commonly involved in wound infections like Escherichia coli, Staphylococcus aureus, Proteus mirabilis, Klebsiella spp., Streptococcus faecalis and Pseudomonas aeruginosa are susceptible to honey regardless of their resistance to antibiotics (Lusby et al., 2005; George and Cutting, 2007; Cooper, 2008).

Although much is documented on the biological activity of honey, no scientific report was seen on the antibacterial activity of honey from three areas in Cameroon. Our objective was to evaluate the in vitro antibacterial activity of honey from Oku, Mbengwi and Ngaoundéré against clinical isolates of $S$. aureus, E. coli, K. pneumonia and $P$. aeruginosa.

\section{MATERIALS AND METHODS Collection and preparation of honey test solutions}

Three natural honey samples including honey from Oku, Mbengwi, and Ngaoundéré regions were collected. These samples were purchased from their respective production sites in sterile screwed cap containers and stored at $5{ }^{\circ} \mathrm{C}$ in the Laboratory of the Regional Hospital Bamenda where the study was carried out from April to May 2016. The honey samples and sterile distilled water were maintained at $37{ }^{\circ} \mathrm{C}$ for six hours before preparing different concentrations of each honey type constituting 20, 40, 60 and 80\% volume per volume $(\mathrm{v} / \mathrm{v})$ prior to testing. Undiluted honey $(100 \%)$ was also used as highest test concentration for each type.

\section{Isolation and characterization of organisms}

The Enterosystem was used to isolate and characterize Escherichia coli (E. coli), and Klebsiella pneumoniae (K. pneumoniae). Enterosystem is a rapid system for the identification of Enterobacteria, a product from LIOFILCHEM diagnostic laboratory in Italy. As procedure, a well isolated colony was picked from MacConkey agar with an inoculating loop and suspended in physiologic saline $(1 \mathrm{ml})$. A quantity of $0.2 \mathrm{ml}$ of the suspension was transferred in to each well using a $1000 \mu \mathrm{l}$ pipette. The wells at position two, three, four, seven and eight were covered with two drops of sterile vaseline oil and then covered and incubated at $37{ }^{\circ} \mathrm{C}$ for $18-24$ hours. After incubation, VP (Vogesproskauer) and IND (Indole) supplementary reagents were added to wells 10 and 11 respectively and the biochemical reactions checked. Using a booklet with colour chart, a numerical code was developed which was matched in a reference book to identify the germ (LIOFILCHEM). In this system, Escherichia coli, was indole positive, glucose positive, lysine decarboxylase (LDC) positive, lactose fermenting, urea negative, citrate negative, and $\mathrm{H}_{2} \mathrm{~S}$ negative. Klebsiella pneumoniae was indole negative, glucose positive, LDC positive, lactose fermenting, urea positive, citrate positive and $\mathrm{H}_{2} \mathrm{~S}$ negative.

Pseudomonas aeruginosa is a Gram negative oxidase positive rod bacterium. It was identified by applying a loop full of colony on the oxidase test strip and observed within thirty seconds. A change from pink to purple indicated a positive reaction. Staphylococcus aureus was identified by performing catalase and coagulase tests. Catalase was used to differentiate 
Staphylococcus species from Streptococcus species, while coagulase was used to differentiate Staphylococcus aureus from other Staphylococcus species. For catalase reaction, a colony was emulsified in hydrogen peroxide on a clean slide and observed for bubbles which indicated a positive reaction. Plasma was mixed with small colonies of the catalase positive organism on a clean slide and rocked to observe for coagulation (Cheesbrough, 2006).

\section{Preparation of microbial suspension for sensitivity testing}

The bacteria considered in this study were clinical isolates obtained from the microbiology section of the laboratory, which are known to cause skin, gastrointestinal and respiratory infections. These organisms were: Staphylococcus aureus, Pseudomonas aeruginosa, Escherichia coli and Klebsiella pneumoniae. These isolates were stored in the refrigerator $\left(2-8{ }^{\circ} \mathrm{C}\right)$ and sub-cultured prior to each testing in their respective media at $37{ }^{\circ} \mathrm{C}$ for 24 hours. Stock bacterial inoculum suspensions were prepared in sterile normal saline. Three-four well isolated colonies were picked using the inoculating loop and suspended in saline under aseptic conditions. Each suspension was adjusted visually to 0.5 McFarland turbidity standards (Cheesbrough, 2006).

\section{Agar well diffusion assay}

In vitro antibacterial activity of honey preparations was evaluated using the agar well-diffusion assay (Ramalivhana et al., 2014; Teke et al., 2011). Prepared Mueller Hinton Agar culture media were brought to room temperature after removal from the refrigerator. The plates were labelled with the names of organisms, date of inoculation, place of origin of honey samples, and the different honey concentrations in $\% \mathrm{v} / \mathrm{v}$. The prepared inoculums were used to flood the cultured plates. Plates were allowed to dry for 30 minutes at $37{ }^{\circ} \mathrm{C}$ and later punched with a sterile cork borer to make six equidistant wells of $5 \mathrm{~mm}$ diameter each, into which $50 \mu \mathrm{l}$ of the different honey concentrations were transferred using a $100 \mu \mathrm{l}$ pipette. These were then allowed to stand for 15 minutes for prediffusion to take place and later incubated at $37{ }^{\circ} \mathrm{C}$ for 24 hours. All plates were later observed for inhibition zone diameters and measured using a ruler. The positive (standard antibiotics ciprofloxacin, $2 \mathrm{mg} / \mathrm{ml}$ ) control was performed by placing $10 \mu \mathrm{g}$ per well (50 $\mu \mathrm{l}$ of $0.2 \mu \mathrm{g} / \mu \mathrm{l}$ solution) at the centres of each plate. Negative control was performed by transferring $50 \mu \mathrm{l}$ sterile distilled water into one of the wells. Each assay was carried out in triplicate and the mean calculated.

\section{Determination of minimum inhibitory concentration (MIC)}

The honey samples $(1 \mathrm{ml})$ were serially diluted separately in $5 \mathrm{ml}$ test tubes previously containing $1 \mathrm{ml}$ Mueller Hinton broth medium to final concentrations of 50 , $25,12.5,6.25,3.125$ and $1.5625 \% \mathrm{v} / \mathrm{v}$. Each microorganism was adjusted to $1.5 \times 10^{8} \mathrm{CFU} /$ $\mathrm{ml}$ and $20 \mu \mathrm{l}$ dispensed into the test tubes. The actual test concentrations of honey now became $49.02,24.51,12.25,6.13,3.06$ and $1.53 \% \mathrm{v} / \mathrm{v}$. Two control tubes were made: a negative control containing honey and broth medium but no microorganisms; a positive control containing broth medium and microorganism but without honey. Ciprofloxacin was used as reference substance in a range from 120 to $0.5 \mu \mathrm{g} / \mathrm{ml}$. All the test tubes were incubated at $37^{\circ} \mathrm{C}$ for $24 \mathrm{~h}$ and the turbidity of each was visually inspected and compared with the controls. The lowest of the honey test concentrations in clear test tubes (Donkeng et al., 2014) was considered as the MIC.

\section{Determination of minimum bactericidal concentration (MBC)}

All the test tubes (for different honey concentrations) indicating no visible sign of growth or turbidity in as observed in MIC determination assay, were further sub-cultured on sterile Mueller Hinton agar plates by streak plate method. The plates were then incubated at $37{ }^{\circ} \mathrm{C}$ for $24 \mathrm{~h}$. The least concentration that did not show growth of test organisms was 
considered as the MBC for each honey sample against a bacterial type.

\section{Determination of $\mathrm{pH}$ for the different honey types}

The $\mathrm{pH}$ measurement was carried out on all the different honey concentrations using CYBOW11 test strips. These strips were dipped into the various honey concentrations, blotted on a tissue paper and the colour change matched with the chart attached to the container to get the $\mathrm{pH}$.

\section{Data management and analysis}

Data on inhibition zone diameters were analysed using statistical package for social sciences (SPSS), version 19. StudentNewman-Keuls test was used to compare inhibition diameters at different test concentrations. MICs and MBCs are expressed as \% of honey.

\section{Ethical considerations}

Administrative authorization was obtained from the Regional Hospital Bamenda to carry out the study.

\section{RESULTS}

\section{Agar well diffusion assay}

The honey samples from Oku, Mbengwi and Ngaoundéré inhibited the growth of all the bacteria under study at concentrations greater than or equal to $40 \%$. The inhibitory zone diameters (Figure 1) produced by the different honey samples are given in Tables 1-3. Honey at 100\% gave the highest inhibitory zone diameters which were observed to decrease with dilution of honey. The bacteria $S$. aureus and E. coli were more susceptible to all the honey samples. This was followed by $P$. aeruginosa and $K$. pneumoniae with decreasing susceptibility. In most cases the activities of these honey samples at concentrations greater than $60 \%$ were comparable to that of the reference drug at $p=0.05$.

\section{MIC and MBC of honey samples}

The MICs and MBCs of the studied honey samples against bacterial growth (Table 4) showed that values range from 12.25 to $49.02 \%$ of honey. The MICs for the Oku, Mbengwi and Ngaoundéré honey samples were the same (12.25\%) for $S$. aureus and $E$. coli, being more sensitive compared to $P$. aeruginosa and K. pneumoniae.

\section{pH of samples}

The $\mathrm{pH}$ was estimated to be 5 for all the honey concentrations.

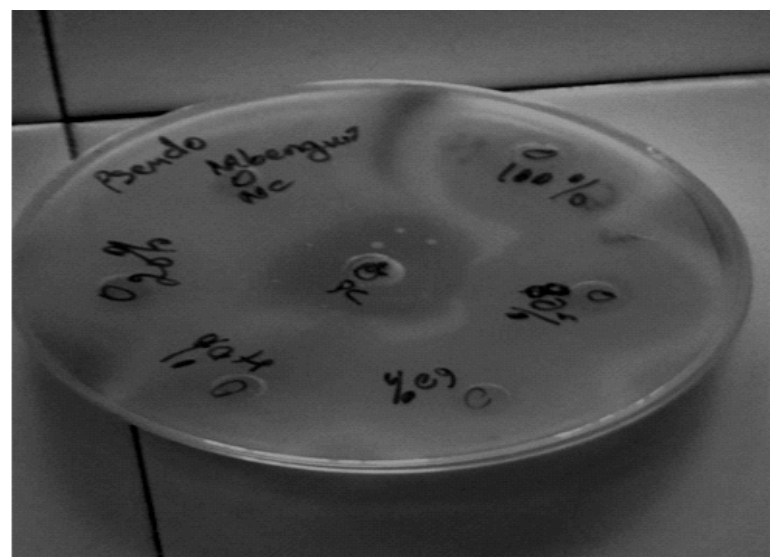

Figure 1: Pseudomonas aeruginosa susceptibility to honey from Mbengwi at various test concentrations. 
Table 1: Inhibitory zone diameters $(\mathrm{mm})$ produced by Oku honey at different concentrations on clinical isolates.

\section{Bacteria}

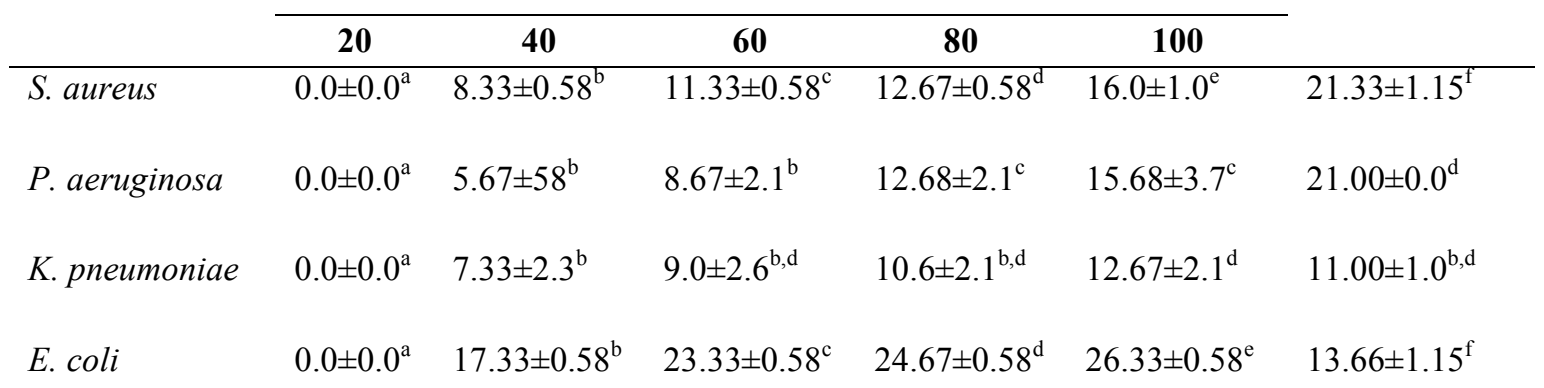

\section{Ciprofloxacin}

\section{Concentration $(\% \mathrm{v} / \mathrm{v})$}

${ }_{\mathrm{a}, \mathrm{b}, \mathrm{c}, \mathrm{d}, \mathrm{e}, \mathrm{f}}$ Indicate significant differences among inhibitory zone diameters for the same bacterium, Student-Newman-Keuls at $p=0.05$.

Table 2: Inhibitory zone diameters ( $\mathrm{mm})$ produced by Mbengwi honey at different concentrations on clinical isolates.

\begin{tabular}{|c|c|c|c|c|c|c|}
\hline \multirow{2}{*}{ Bacteria } & \multicolumn{5}{|c|}{ Concentration $(\% \mathrm{v} / \mathrm{v})$} & \multirow{2}{*}{ Ciprofloxacin } \\
\hline & 20 & 40 & 60 & 80 & 100 & \\
\hline S. aureus & $0.0 \pm 0.0^{\mathrm{a}}$ & $18.0 \pm 1.0^{b}$ & $22.33 \pm 1.52^{\mathrm{c}}$ & $25.67 \pm 1.52^{\mathrm{d}}$ & $27.0 \pm 1.0^{\mathrm{d}}$ & $21.33 \pm 1.15^{\mathrm{c}}$ \\
\hline P. aeruginosa & $0.0 \pm 0.0^{\mathrm{a}}$ & $9.0 \pm 1.7^{\mathrm{b}}$ & $13.17 \pm 1.8^{\mathrm{c}}$ & $16.67 \pm 0.58^{d}$ & $20.33 \pm 0.58^{\mathrm{e}}$ & $21.00 \pm .00^{\mathrm{e}}$ \\
\hline K. pneumoniae & $0.0 \pm 0.0^{\mathrm{a}}$ & $7.33 \pm 3.2^{\mathrm{b}}$ & $9.33 \pm 4.0^{\mathrm{b}}$ & $11.33 \pm 4.0^{\mathrm{b}}$ & $13.0 \pm 4.4^{\mathrm{b}}$ & $11.00 \pm 1.0^{\mathrm{b}}$ \\
\hline E. coli & $0.0 \pm 0.0^{\mathrm{a}}$ & $13.0 \pm 2.64^{\mathrm{b}}$ & $21.68 \pm 1.2^{\mathrm{c}}$ & $23.67 \pm 1.2^{\mathrm{c}, \mathrm{d}}$ & $26.0 \pm 2.0^{\mathrm{d}}$ & $13.66 \pm 1.15^{\mathrm{b}}$ \\
\hline
\end{tabular}

Table 3: Inhibitory zone diameters $(\mathrm{mm})$ produced by Ngaoundéré honey at different concentrations on clinical isolates.

\begin{tabular}{|c|c|c|c|c|c|c|}
\hline \multirow{2}{*}{ Bacteria } & \multicolumn{5}{|c|}{ Concentration (\% v/v) } & \multirow{2}{*}{$\begin{array}{c}\text { Ciprofloxaci } \\
n\end{array}$} \\
\hline & 20 & 40 & 60 & 80 & 100 & \\
\hline S. aureus & $0.0 \pm 0.0^{\mathrm{a}}$ & $21.33 \pm 1.2^{\mathrm{b}}$ & $24.0 \pm 1.0^{\mathrm{c}}$ & $25.67 \pm 0.58^{\mathrm{d}}$ & $27.67 \pm 0.58^{\mathrm{d}}$ & $21.33 \pm 1.15^{\mathrm{b}}$ \\
\hline P. aeruginosa & $0.0 \pm 0.0^{\mathrm{a}}$ & $10.0 \pm 3.5^{b}$ & $16.33 \pm 2.1^{\mathrm{c}}$ & $21.0 \pm 1.7^{\mathrm{d}}$ & $24.0 \pm 1.0^{\mathrm{d}}$ & $21.00 \pm 0.0^{\mathrm{d}}$ \\
\hline K. pneumoniae & $0.0 \pm 0.0^{\mathrm{a}}$ & $8.0 \pm 1.0^{\mathrm{b}}$ & $9.67 \pm 0.58^{\mathrm{b}}$ & $11.67 \pm 1.2^{\mathrm{c}, \mathrm{d}}$ & $14.0 \pm 2.6^{\mathrm{d}}$ & $11.00 \pm 1.0^{\mathrm{c}}$ \\
\hline E. coli & $0.0 \pm 0.0^{\mathrm{a}}$ & $18.33 \pm 1.2^{\mathrm{b}}$ & $22.33 \pm 0.58^{\mathrm{c}}$ & $24.33 \pm 0.58^{\mathrm{d}}$ & $26.33 \pm 0.58^{\mathrm{e}}$ & $13.66 \pm 1.15^{\mathrm{f}}$ \\
\hline
\end{tabular}


Table 4: MICs and MBCs of honey samples against bacterial growth.

\begin{tabular}{|c|c|c|c|c|c|c|c|c|}
\hline \multirow{3}{*}{ Bacteria } & \multicolumn{6}{|c|}{ Honey samples (\%) } & \multirow{2}{*}{\multicolumn{2}{|c|}{$\begin{array}{l}\text { Ciprofloxacin } \\
(\mu \mathrm{g} / \mathrm{ml})\end{array}$}} \\
\hline & \multicolumn{2}{|c|}{ Oku } & \multicolumn{2}{|c|}{ Mbengwi } & \multicolumn{2}{|c|}{ Ngaoundéré } & & \\
\hline & MIC & MBC & MIC & MBC & MIC & $\mathrm{MBC}$ & MIC & MBC \\
\hline S. aureus & 6.13 & 49.02 & 6.13 & 49.02 & 6.13 & 49.02 & 2 & 8 \\
\hline P. aeruginosa & 12.25 & 49.02 & 24.51 & 49.02 & 12.25 & 49.02 & 8 & 16 \\
\hline K. pneumoniae & 24.51 & 49.02 & 24.51 & 49.02 & 24.51 & 49.02 & 64 & 120 \\
\hline E. coli & 6.13 & 49.02 & 6.13 & 49.02 & 12.25 & 49.02 & 2 & 8 \\
\hline
\end{tabular}

\section{DISCUSSION}

In the present study, honey samples from Oku, Mbengwi and Ngaoundéré were tested for their in vitro antibacterial activities. The results obtained showed that the tested honeys exhibited a level of antibacterial activity which generally increased with increase in honey concentration. The different honeys possessed potential antibacterial activity against Gram negative bacterium ( $E$. coli). This is in accordance with the previous report by Mohapatra et al. (2011), indicating that raw and processed honeys have potential activity against this bacterium. Oku honey had moderate growth inhibitory effects on $P$. aeruginosa, $K$. pneumoniae and $S$. aureus. Some honey types (Yemeni Sidr and Egyptian honeys) are observed to have moderate activity on these microorganisms compared to others (Amal, 2014). The degree of antibacterial activity varied according to the type of bacterium and type of honey. The observed differences in the activity of the different honeys at various concentrations, may suggest that site difference, as well as the nature of honey production influence their inhibitory activities (Manisha and Shyamapada, 2011). Some reasons for variations seen between bacteria response to honeys might be due to difference in their cellular organization of the bacteria.

The $\mathrm{pH}$ was estimated for all the different honeys and their concentrations using CYBOW 11test strips to be 5 , which is acidic. This is in agreement to the work done by Ball (2007), showing that honey is acidic.

Moreover, high osmotic effect (about 80\% $\mathrm{wt} / \mathrm{vol}$ of concentrated sugars) (Ramalivhana et al., 2014) and microorganism sensitivity to hydrogen peroxide (produced by glucose oxidase originating from the bees) found in honey (Ramalivhana et al., 2014; Paulus et al., 2008) constitute inhibitory factors to bacterial growth (Amal, 2014; Manisha and Shyamapada, 2011).

The MICs and MBCs values for all the tested honeys showed potential bactericidal and bacteriostatic activities against the studied bacteria. Our results corroborate with those of other researchers (Allen et al., 2000; Getaneh et al., 2013; Ahmed et al., 2014). S. aureus was more sensitive to the honey samples. This bacterium is known to infect wounds and being susceptible to our honey types implies that theses honey could be applied externally for wound treatment. It is documented that honey is used in the treatment of infected wound (Kingsley, 2001).

It was observed that the $\%(\mathrm{v} / \mathrm{v})$ of $\mathrm{Oku}$, Mbengwi and Ngaoundéré honey samples that completely inhibited growth for $S$. aureus, E. coli, K. pneumoniae and $P$. aeruginosa varied from $6.13-24.51 \%$. Our values are similar to the results of Wasihun and Kasa (2016) but at the same time higher than those (1.8 to $10.8 \%$, and 10 to $11.5 \%$ ) cited in the work of Wasihun and Kasa (2016) and the report of Getaneh etal. (2013) respectively on the antibacterial activity of Tazma honey on MRSA. These differences in the antibacterial activity of honeys could be due to the different sources and/or species of bees (Wasihun and Kasa, 2016) responsible for honey making. Elsewhere, alkaloids, tannins, flavonoids were found in honey samples (Adeniyi et al., 2016). These compounds are known to possess antibacterial activities (Adeniyi et al., 2013; Houria et al., 2014; Zintchem et al., 2015) and could be responsible for the differential antimicrobial activities observed in this study. Other variables such as weather and climatic 
changes (Wasihun and Kasa, 2016) influence honey growth inhibitory action on microorganisms.

\section{Conclusion}

The honey samples from Oku, Mbengwi and Ngaoundéré showed considerable antibacterial activity against $S$. aureus, E. coli, $P$. aeruginosa and $K$. pneumoniae which are known to cause infectious diseases in humans. However, further studies on the standardization and clinical evaluation on the effect of this natural substance are needed for its wide use in the prevention and treatment of bacterial infections.

\section{COMPETING INTERESTS}

The authors declare that they have no competing interests.

\section{AUTHORS' CONTRIBUTIONS}

GNT conceived the study, designed the method, monitored the experimental and laboratory work, analyzed data, drafted and finalized the manuscript for publication. BEN did the experimental and laboratory work, collected and transported data and other materials. All authors read and approved the final manuscript.

\section{ACKNOWLEDGEMENTS}

We thank the laboratory staff of the Regional Hospital Bamenda for their technical assistance.

\section{REFERENCES}

Adeniyi BA, Izuka KC, Odumosu B, Aiyelaagbe OO. 2013. Antibacterial and antifungal activities of methanol extracts of Desmodium adscendens root and Bombax buonopozense leaves. Int. J. Biol. Chem. Sci., 7(1): 185-194. DOI: http://dx.doi.org/10.4314/ijbcs.v7i1i.15.

Anna F, Yeoungjee C, Johnson W. 2015. Honey in the Prevention and Treatment of Infection in the CKD Population: A Narrative Review. Evidence-Based Complementary and Alternative
Medicine,
http://dx.doi.org/10.1155/2015/261425. http://dx.doi.org/10.1155/2015/261425. MB, Mohammed SS, Bashir L, Yusuf RS. 2016. Comparative phytochemical and antinutritional constituents of Nigeria sweet and bitter honey varieties. World Journal of Pharmaceutical Research, 5(3): 255-267.

Ahmed M, Sahile S, Subramanian C. 2014. Evaluation of antibacterial potential of honey against some common human pathogens in North Gondar zone of Ethiopia. Int. J. Pure Appl. Zool., 2(4): 286-295.

Allen KI, Radwan S, Reid GM. 2000. Antimicrobial activity of honey on some microbial isolates. J. Med. Pharm. Sc., 2: 75-79.

Amal SO. 2014. Antibacterial Activity of Bee and Yemeni Sidr Honey Against Some Pathogenic Bacterial Species. Int. J. Curr. Microbiol. App. Sci., 3(10): 1015-1025.

Ball D. 2007. The chemical composition of honey. J. Chem. Educ., 84: 1643-1646. DOI: $10.1021 /$ ed084p1643.

Cheesbrough M. 2006. District Laboratory Practice in Tropical Countries ( $2^{\text {nd }}$ edn). Cambridge University Press, New York; 178-194.

Chute RK, Deogade NG, Kawale M. 2010. Antimicrobial activity of Indian honey against clinical Isolates. Asiatic $J$. Biotech. Res., 1: 35-38.

Cooper RA. 2008. Using honey to inhibit wound pathogens. Nurs. Times, 104(3): 46-49.

Donkeng DVF, Roque S, Trigo G, Tsouh FPV, Yamthe TLR, Tsabang N, Amvam ZPH, Margarida CN, Fekam FB. 2014. Antimycobacterial activity of selected medicinal plants extracts from Cameroon. Int. J. Biol. Chem. Sci., 8(1): 273-288. DOI: http://dx.doi.org/10.4314/ijbcs.v8i1.24

George NM, Cutting KF. 2007. Antibacterial Honey (Medihoney): In vitro Activity Against Clinical Isolates of MRSA, VRE, and Other Multiresistant Gram-negative Organisms Including Pseudomonas. Wounds, 19(9): 231-236.

Getaneh A, Belyhun Y, Moges F, Anagaw B, Destaw B, Unakal C. 2013. In vitro 
assessment of the antimicrobial effect of Ethiopian multi-flora honey on methicillin resistant Staphylococcus aureus. J. Curr. Res. Rev., 5(11): 64-72.

Houria A, Esma F, Rabah D, Dounia M. 2014. In vitro antibacterial activity of Pituranthos scoparius from Algeria. Int. J. Biol. Chem. Sci., 8(5): 2095-2108. DOI:

http://dx.doi.org/10.4314/ijbcs.v8i5.15.

Kingsley A. 2001. The use of honey in the treatment of infected wound. Br. J. Nurs., 10(22): 13-16, S18, S20. DOI:10.12968/bjon.2001.10.Sup5.12323.

Kwakman P, Velde A, Boer L, Speijer D, Vandenbroucke-Grauls C, Zaat S. 2010. How honey kills bacteria. FASEB J., 24: 2576-2582. DOI:10.1096/fj.09-150789.

Kwakman PH, Zaat SA. 2012. Antibacterial components of honey. IUBMB Life, 64(1): 48-55. DOI: 10.1002/iub.578.

Lusby PE, Coombes AL, Wilkinson JM. 2002. Honey: a potent agent for wound healing. J. Wound Ostomy Cont. Nurs., 29: 295-300.

Lusby PE, Coombes AL, Wilkinson JM. 2005. Bactericidal Activity of Different Honeys against pathogenic bacteria. Arch. Med. Res., 36: 464-467. DOI:10.1016/j.arcmed.2005.03.038.

Mahendran S, Kumarasamy D. 2015. Antimicrobial activity of some honey samples against pathogenic bacteria. Int. Let. Nat. Sc., 7: 15-20.

Maria LE, Afonso SE, Xesus F. 2011. Antifungal effect of lavender honey against Candida albicans, Candida krusei, and Cryptococcus neoformans. J. Food Sci. Technol., 48(5): 640-643. DOI: 10.1007/s13197-011-0243-1.

Manisha DM, Shyamapada M. 2011. Honey: its medicinal property and antibacterial activity. Asian Pacif. J. Trop. Biomed., 1(2): 154-160. DOI: 10.1016/S22211691(11)60016-6.

Mohapatra DP, Thakur V, Brar SK. 2011. Antibacterial Efficacy of Raw and Processed Honey. Biotechnology Research International, 2011. DOI:10.4061/2011/917505.

Paulus HS, Kwakman, Johannes PC, Van den A, Ahmet G, Hamid A, Jan MB, Leonie de B, Boszhard L, Paulus F, Middelhoek P, Velde AA, Vandenbroucke-Grauls CMJE, Schultz MJ, Zaat SAJ. 2008. Medical-Grade Honey Kills AntibioticResistant Bacteria In Vitro and Eradicates Skin Colonization. Clinical Infectious Diseases, 46: 1677-82. DOI: 10.1086/587892.

Ramalivhana JN, Obi CL, Samie A, Iweriebor BC, Uaboi-Egbenni P, Idiaghe JE, Momba MNB. 2014. Antibacterial activity of honey and medicinal plant extracts against Gram negative microorganisms. Afr. J. Biotechnol., 13(4): 616-625. DOI: 10.5897/AJB11.892.

Shears P. 2000. Antimicrobial resistance in the tropics. Tropical Doctor, 30(2): 114116.

Subrahmanyam M, Hemmady A, Pawar SG. 2001. Antibacterial activity of honey on bacteria isolated from wounds. Ann. Burns Fire Disasters, 14: 198-201.

Teke GN, Kuiate JR, Kueté V, Teponno RB, Tapondjou LA, Tane P, Giacinti G, Vilarem G. 2011. Bio-guided isolation of potential antimicrobial and antioxidant agents from the stem bark of Trilepisium madagascariense. South African Journal of Botany, 77: 319-327.

Wasihun AG, Kasa BG. 2016. Evaluation of antibacterial activity of honey against multidrug resistant bacteria in Ayder Referral and Teaching Hospital, Northern Ethiopia. Springer Plus, 5: 842. DOI: 10.1186/s40064-016-2493-X.

Zainol MI, Yusoff KM, Yusof MYM. 2013. Antibacterial activity of selected Malaysian honey. BMC Complementary and Alternative Medicine, 13: 129. DOI: 10.1186/1472-6882-13-129.

Zintchem R, Fankem GO, Fokunang C, Mkounga P, Achick ET, Kamgang R, Gatsing D, Dimo T. 2015. In vitro evaluation of the antimicrobial properties of Mallotus oppositifolium decoction leaf extracts and fractions. Int. J. Biol. Chem. Sci., 9(2): $\quad 815-824$. DOI: http://dx.doi.org/10.4314/ijbcs.v9i2.21. 